This is the author's manuscript for publication. The publisher-formatted version may be available through the publisher's web site or your institution's library.

\title{
Fair trade consumption from the perspective of US Baby Boomers
}

Ebony Benson and Kim Y. Hiller Connell

\section{How to cite this manuscript}

If you make reference to this version of the manuscript, use the following information:

Benson, E., \& Connell, K. Y. H. (2014). Fair trade consumption from the perspective of US baby boomers

\section{Published Version Information}

\section{Citation:}

Benson, E., \& Connell, K. Y. H. (2014). Fair trade consumption from the perspective of US baby boomers. Social Responsibility Journal, 10(2), 364-382.

Digital Object Identifier (DOI): 10.1108/SRJ-08-2012-0094

Publisher's Link: http://www.emeraldinsight.com/doi/pdfplus/10.1108/SRJ-08-2012$\underline{0094}$ 


\section{Fair Trade Consumption from the Perspective of U.S. Baby Boomers}

\section{Introduction}

The intention of this empirical research study is, through a survey research method, to expand the knowledge base related to fair trade consumption by examining U.S. Baby Boomers', attitudes and behaviours towards fair trade products. As a generational cohort with tremendous financial assets and greater consumer expenditures compared to younger generations, Baby Boomers have remarkable purchasing power and the potential to increase total sales of fair trade products (Hurley, 2010; Morrissey, 2012; Neal, 2010; U.S. Department of Labor, 2012). Also of interest in this study are the perceived barriers that may be limiting Baby Boomers from consistently purchasing fair trade products. Furthermore, this study sets out to compare the fair trade attitudes and behaviours of Early and Late Baby Boomers.

The fair trade movement ${ }^{1}$, with merchandise that typically includes food products (such as coffee, tea, and produce) and non-food products (such as apparel, jewellery, handicrafts, and body care), emerged during the 1940s and the movement has grown over the last 70 years as cognizance of it has increased among consumers (Connolly and Shaw, 2006). As of 2011, there were close to 1000 producer organizations in over 66 countries growing, processing, creating, and selling products certified as fair trade (Fairtrade International, 2012). Moreover, global sales of fair trade in 2011 equalled $\$ 7.7$ billion (USD) and in the United States, more than 11,000 fair trade certified products are available in over 60,000 retail locations (Fair Trade USA, 2011). However, according to Niinimaki (2010: 151) although “consumer's attitudes towards [fair

\footnotetext{
${ }^{1}$ The fair trade movement was founded on the idea of paying just wages and providing safe working conditions to marginalized producers in developing countries (Downie, 2007). The movement aims to improve the quality of life for producers, provide producers with opportunities for development, educate consumers about the negative consequences of international trade on producers, lobby and change international trade policies, and promote human rights (Moore, 2004).
} 
trade] are positive... actualization of ethical interest into ethical purchasing decisions is more complex," and the overall number of consumers who consistently purchase fair trade products remains small. For example, within the United States total sales of fair trade merchandise in 2008 equalled a little over $\$ 1$ billion - one fortieth of total sales within the U.S. for certified organic goods (Hainmueller and Hiscox, 2012).

In order to grow fair trade markets further, it is important to explore potential new market segments and expand on current markets. Having a better understanding of the defining attributes of consumers within those new segments will help fair trade entities. One such potential target market is Baby Boomer consumers. According to Scarborough Research (2012), Baby Boomers make up $35 \%$ of the adult population in the United States and have significant disposable incomes (Hurley, 2010; Neal, 2010). Therefore, the size and purchasing power of this generation makes Baby Boomers a lucrative target market that could be capitalized on by fair trade organizations. Although some Baby Boomers may already be purchasing fair trade products, those consumers remain a small percentage of all Boomers. Therefore, the aim of this research is to gain more information about Baby Boomers' attitudes and behaviours related to fair trade with the goal of encouraging greater consumption of fair trade among this generation.

Following this introduction, the paper provides an overview of the unique demographic and psychographic characteristics of the Baby Boomer generation. The paper then proceeds to outline the theoretical framework and previous literature guiding the study, as well as the research method used. The fourth section of the paper presents the findings of the study, first by summarizing the demographic characteristics of the respondents and then detailing the study's results. Finally, the paper concludes with implications and suggestions for future research.

\section{The U.S. Baby Boomer Generation}


Although many countries, including Canada, Australia, New Zealand, and numerous European countries, experienced a post-World War II population boom, this study focuses on Baby Boomers within the United States. U.S. Baby Boomers were born between the years 1946 and 1964. There are approximately 78 million Baby Boomers living in the United States and someone in the U.S. turns 50 every seven seconds. They currently make up approximately $26.5 \%$ of the total population of the United States and within the cohort, $48.5 \%$ are male and $51.5 \%$ are female (U.S. Census Bureau, 2011).

Baby Boomers in the United States experienced post-World War II prosperity, attained high levels of education, and financially benefitted from the rapid growth of the economy during the 1980s and 1990s (Nyren, 2005). Within the U.S., Baby Boomers hold \$13 trillion (USD) in assets, which is $50 \%$ of the country's total asset base (Hurley, 2010). Baby Boomers have an estimated spending power of $\$ 2$ trillion (USD) a year (Neal, 2010); and despite, the economic crisis of 2008, U.S. Baby Boomers to continue to maintain a net worth three times greater than younger generations (Morrissey, 2012). Furthermore, annually U.S. Boomers spend $\$ 400$ billion (USD) more on consumer goods and services compared to younger generations, outspending average consumers in categories such as household furnishings, entertainment, personal care, and gifts (U.S. Department of Labor, 2012).

U.S. Baby Boomers are avid television watchers, watching 13 hours more per week than Millennials (born between the years 1982 and 1991) (Ferguson and Brohaugh, 2010). Boomers are also Internet enthusiasts—with 77\% of Baby Boomers in the U.S. having Internet access (Ferguson and Brohaugh, 2010). While Millennials dominate most social networking sites, Boomers use of social networking sites increased by $59 \%$ in 2009, while Millennials' use only increased by 2\% (Ferguson and Brohaugh, 2010). Furthermore, Ferguson and Brohaugh (2010) 
report that in 2007, online spending for women between the ages of 42 and 62 averaged $\$ 380$ per year, compared with $\$ 285$ a year for Millennials and $\$ 364$ for Generation Xers (born between 1965 and 1981).

Wolfe and Snyder (2003) suggest a person most identifies with people within six to seven years of their age, making the ideal range for generational cohorts 12 to 14 years. Baby Boomers are a generational cohort spanning 19 years. Therefore, two subgroups frequently divide the cohort: Early (or Leading) Baby Boomers and Late (or Trailing) Baby Boomers. Early Baby Boomers were born between the years of 1946 and 1954, while Late Baby Boomers were born between the years of 1955 and 1964 (Green, 2003; Wellner, 2000).

In the United States, Early and Late Baby Boomers differ in some life experiences. Early Boomers came to age during the civil rights, environmental, and feminist movements. They can remember the deaths of President John F. Kennedy and Martin Luther King, Jr. On the other hand, Late Boomers entered college and young adulthood after the Vietnam War. They experienced less social and political upheaval and were young adults during a more peaceful time. Early and Late Boomers are also presently at different life stages. Early Baby Boomers have started reaching retirement age and are seriously planning for their next life stage. Many of their children are in college or have established careers and families of their own. These Boomers are looking for new experiences and are seeking personal development. On the other hand, most Late Baby Boomers are still working and have children in grade school and living at home (Green, 2003). Considering these differences between Early and Late Boomers, it stands to reason they may also differ in consumer behaviours - a possibility further explored in this study.

\section{Theoretical Framework and Review of Literature}

The ABC Model 
Stern and Oskamp (1987) assert that engagement in socially responsible behaviour is the result of both internal and external factors. Internal factors include personal attitudes, beliefs, and knowledge unique to the individual. External factors include economic forces, social institutions, and physical structures, which are on the macro-level and are out of the individual's realm of control. Building upon Stern and Oskamp, through the ABC model, Guagnano et al. (1995: 702) propose that, "actions or behaviours (B) are associated with attitudes (A)... Actions also have external conditions (C) associated with them" (see Figure 1). The ABC model states that there are varying degrees of attitudes and external conditions when it comes to behaviour and the importance of the behaviour mirrors the degree of importance placed on the internal or external factors. If the behaviour is found to be comparable to the need but has strong negative external conditions and is "difficult, expensive or inconvenient for most members of the population [it] will result in the action being relatively rare, whereas those associated with strong positive conditions will be very common" (Guagnano et al., 1995: 702). In the model, the "value" placed on the attitudes by the individual and the external conditions determine the possibility of the behaviour occurring.

$* *$ Insert Figure $1 * *$

In the context of fair trade purchasing behaviours, according to the ABC Model, if the external conditions working against fair trade consumption are minimal, consumers with favourable attitudes towards fair trade are more likely to engage in fair trade purchasing behaviours that are consistent with those attitudes. However, if the external conditions are such that it becomes difficult to engage in fair trade consumption, even if an individual has positive attitudes about fair trade, the person is unlikely to purchase fair trade, leading to inconsistency 
between his or her attitudes and behaviours. Therefore, encouraging greater levels of fair trade purchasing within the Baby Boomer market segment requires an examination of their fair trade attitudes as well as the external conditions that this consumer group may perceive as being barriers limiting their engagement in this behaviour.

\section{Internal Factors and Fair Trade Consumption}

Ethical consumption is the decision-making process involved with purchasing that takes into account the consumers' ethical concerns (Barnett et al., 2005; De Pelsmacker et al., 2005). An ethical consumer is a person who feels some measure of responsibility towards society and uses buying behaviours to communicate those attitudes (De Pelsmacker et al., 2005). Some forms of ethical consumption are primarily concerned with the natural environment, commonly referred to as green or eco-conscious consumption (Uusitalo and Oksanen, 2004). Other forms of ethical consumption, including fair trade consumption, are concerned with people (Nicholls, 2002).

Demographically, previous research indicates that consumers of fair trade products tend to be well educated and have above average incomes (Adams and Raisborough, 2008, Bird and Hughes, 1997; De Pelsmacker et al., 2005). Additionally the typical consumer of fair trade products is female and middle aged (Bird and Hughes, 1997; Castaldo et al., 2008; De Pelsmacker et al., 2005; Dickson and Littrell, 1997; Hulm, 2006).

Regarding the attitudes of fair trade consumers, research demonstrates that the typical fair trade consumer is idealistic (De Pelsmacker et al., 2005) and has a strong sense of world citizenship and empathy towards others in developing countries (Dickson and Littrell, 1996, 1997; Ozcaglar-Toulouse et al., 2006). They have a positive attitude towards fair trade products and perceive it easy to purchase fair trade goods (Ozcaglar-Toulouse et al., 2006) Furthermore, 
many fair trade consumers indicate a willingness to sacrifice price and quality to buy fair trade products (De Pelsmacker et al., 2005; Dickson and Littrell, 1996).

There is a lack of research examining factors influencing fair trade purchasing behaviours within the context of generational cohorts. However, one study by Littrell et al. (2005) explored three generational cohorts (Generation Xers, Baby Boomers, and the Swing Generation) and how the cohorts differed in terms of fair trade product attitudes and buying behaviours, retail preferences, shopping orientations, and socio-political attitudes. Littrell et al. (2005) also studied how those factors influenced purchase intentions for fair trade apparel. Significant findings of the study were that Swing and Baby Boomers differed from Generation X in that the older generations were more likely to want the fair trade apparel to be comfortable and of high quality. They were also more apt to buy authentic products that were native to the producer and ethnic attire. On the other hand, Generation Xers desired fair trade products that were fashionable.

\section{External Conditions and Fair Trade Consumption}

In this study, diffusion theory (Rogers, 2003) provides the framework for examining the external conditions that may impede Baby Boomer's adoption of fair trade purchasing behaviours. Within this theory, the diffusion process is defined as an orderly sequence of events that consist of the introduction of an innovation (in this case fair trade), adoption, increase, peak, then eventual decline or obsolescence (Rogers, 2003). Additionally, diffusion theory defines an innovation as something that is not necessarily brand new to the market, just newly introduced to an individual consumer (Rogers, 2003). Therefore, this study considers fair trade an innovation to Baby Boomers who have never been directly targeted as consumers of fair trade.

Prerequisites for adoption of an innovation. According to diffusion theory, five variables determine the success or failure of an innovation. Rogers (2003) refers to these variables as 
prerequisites to the adoption of an innovation and they include compatibility, trialability, complexity, observability, and relative advantage. This current study examines barriers to the wide spread adoption of fair trade products among the Baby Boomer generation within the context of Rogers' (2003) prerequisites.

Within diffusion theory, compatibility is how well the innovation is connected to a person's lifestyle and reflective of his or her values (Rogers, 2003). As it relates to fair trade, compatibility refers to if the product fits "personal style" or is consistent with the existing norms and values of consumers (Jøergens, 2006). As the literature conveys, consumers may be supportive of the principles of fair trade but may be unwilling to compromise other desired product attributes such as quality and aesthetics. As well, consumers choose products that are consistent with their lifestyle and the functionality of fair trade products may not fit with that lifestyle (Forney et al., 2005).

A study by Halepete et al. (2009) on the personalization of fair trade apparel, found that some consumers were unhappy with fair trade apparel because the designs, patterns, and colours were not compatible with their personal style. In fact, a majority of the respondents agreed they would be more willing to purchase fair trade products if there were a greater range in product selection—allowing them to purchase products more compatible with their personalities and lifestyles. Similarly, Shaw et al. (2006) found the perceived unfashionable nature of fair trade apparel a factor limiting consumption and Dickson and Littrell (1996) learned that consumers believed that fair trade products were not as durable as products available in the mainstream market and thus incompatible with their quality standards.

The price of fair trade merchandise may also be incompatible with a consumer's lifestyle and limit intentions to make fair trade purchases. For example, Shaw et al. (2006) reported price 
to be one of the most significant barriers preventing people from engaging in more fair trade consumer behaviours. Fair trade merchandise typically carriers a higher price point compared to mainstream products and research shows many consumers believe the cost to be financially incompatible with their lives.

Trialability, the second prerequisite to adoption of an innovation, relates to whether or not the individual can experience the innovation before deciding on adoption or rejection (Rogers, 2003). Because many fair trade retailers sell through catalogues or online, consumers cannot see, touch, or try the product prior to purchase. Therefore, there is a high risk associated with the purchase that many consumers are not willing to tolerate-leading to the absence of the prerequisite of trialability as also being a potential barrier to fair trade consumption (Shaw et al., 2006).

The prerequisite of complexity concerns the difficulty of use or understanding of an innovation (Rogers, 2003). In relation to fair trade, consumers may have some difficulty understanding the principles of fair trade and may have to participate in extensive problem solving" (Uusitalo and Oksanen, 2004). Some consumers may not want to take this additional decision-making step and will purchase more familiar (and non-fair trade) products. Even when the consumer has a basic understanding of the meaning of fair trade and has access to products that are fair trade certified, fair trade is very complex and it can be difficult for consumers to define unethical behaviour, as well as for them to make judgments about the ethics of individual brands and products (Jøergens, 2006). Therefore, the complexity of fair trade consumption can serve as a barrier to adoption.

Observability, the fourth prerequisite to the adoption of an innovation, is determined by how visible the product is and if it communicates effectively (Rogers, 2003); and it may be one 
of the most complex factors within the consumption of fair trade products. Labelling is a major issue in the fair trade movement and many fair trade products are not actually fair trade certified and do not carry a fair trade logo (Verdier-Stott, 2009). As a result, consumers have to trust the word of fair trade companies and make inferences about whether the product is or is not ethically produced; and Shaw et al. (2006) found the lack of information provided by companies about the origins of garments a barrier identified by consumers as limiting their fair trade apparel purchases.

Within diffusion theory (Rogers, 2003), relative advantage is the fifth prerequisite to the adoption of an innovation — an innovation must have relative advantage over competing products before consumers will adopt the innovation. Because fair trade products are socially and environmentally conscious and the purchase of these products improves the quality of life for producers and their communities, an assumption of this study is that, for many consumers, fair trade products innately have a strong relative advantage over comparable mainstream products. Therefore, this study does not perceive relative advantage as a barrier to the adoption of fair trade. Instead, it proposes that, in marketing fair trade products, fair trade entities are underutilizing this prerequisite and marketing efforts should better demonstrate the relative advantage of fair trade over other products.

To summarize, many variables determine if consumers will successfully adopt a fair trade product. This study seeks to examine barriers against fair trade purchasing by examining the role of the first four prerequisites (compatibility, trialability, observability, and complexity) that determine the success of an innovation. The fifth prerequisites, relative advantage, will be assessed in terms of how current fair trade marketing practices can be improved to reflect its competitive advantage of fair trade goods over more mainstream merchandise. 
Therefore, given the above considerations, the overall purpose of this study is to explore fair trade consumption among Baby Boomers within the United States. More specifically, the objectives for the study are to: 1) explore U.S. Baby Boomers' attitudes about fair trade, as well as their engagement in fair trade purchasing behaviours; 2) identify the barriers facing U.S. Baby Boomers in the purchasing of fair trade products; and 3) investigate differences between Early and Late Baby Boomers' fair trade related attitudes and behaviours. Finally, based on the research findings the study proposes methods for fair trade entities to successfully market fair trade products to Baby Boomer consumers.

\section{Research Method}

\section{Survey Instrument}

This study employed survey research method and data were collected through an online questionnaire (see Table 1) that addressed a range of questions related to fair trade. The questionnaire consisted of four sections: 1) attitudes about the fair trade movement; 2) engagement in fair trade purchasing behaviours; 3) barriers to fair trade purchasing; and 4) demographic information.

\section{** Insert Table $1 * *$}

To measure consumers' attitudes about the fair trade movement, this study adapted the scale developed by Dickson (1999) in the context of socially responsible apparel consumption. Previous studies have also utilized this scale, always with coefficient estimates for reliability at .70 or higher (Hiller Connell and Kozar, 2012a, 2012b; Kozar and Hiller Connell, in press, 2010). The original Dickson (1999) scale measured knowledge of and concern with social issues related to the apparel industry, and the scale included 23 items. For this study, the researchers selected eight items from Dickson's scale that measured consumer attitudes and modified the 
wording so each item was within the context of fair trade. This portion of the questionnaire asked consumers to indicate their level of agreement with statements about fair trade on a 7-point Likert-like scale (1=strongly disagree to $7=$ strongly agree). Examples of statements included, "I am concerned with issues affecting people in developing countries around the world," and, "I believe in the principles of fair trade."

There were two scales used to measure fair trade purchasing behaviour. The purpose of the first behaviour scale was to measure engagement in fair trade purchasing behaviour on a broad level. This scale, the Fair Trade Purchasing Behaviours (FTPB) scale, included four items adapted from Kozar and Hiller Connell (2010), along with three additional items developed for this study. The Kozar and Hiller Connell (2010) scale measures consumers' participation in sustainable apparel purchasing behaviours and it includes four items that assess previous engagement in environmentally conscious behaviours and four items that assess previous engagement in socially responsible behaviours. Previous studies have also utilized this scale, always with coefficient estimates for reliability at .70 or higher (Hiller Connell and Kozar, 2012a, 2012b; Kozar and Hiller Connell, 2010, in press). Therefore, to develop the FTPB scale for this study, the researchers selected the four items from Kozar and Hiller Connell (2010) measuring socially responsible purchasing behaviours and modified the items to focus on fair trade purchasing behaviours. For example an original item in Kozar and Hiller Connell (2010) states, "In the past, I have paid more for clothes and accessories that I knew were made under fair labour standards." In this study, the item was modified as, "I pay more for products that I know are made under fair trade principles." The scale asked respondents to indicate how often they had engaged in certain fair trade purchasing behaviours on 6-point Likert-type scales $(0=\mathrm{I}$ do not know to 5=All of the time). Examples of statements included, "I buy fair trade products," 
and, "I actively seek out information about the conditions in which products are manufactured before I purchase them."

The purpose of the second behaviour scale, developed specifically for this study, was to determine the frequency with which the respondents purchased certain types of fair trade products. This scale asked, "In the last 6 months, how often have you bought the following fair trade products?" The products included coffee, jewellery, clothing, chocolate, handbags, and home fashions and the response categories included none, one to two times, three to four times, five to six times, and seven or more times.

To assess consumers' perceived barriers to fair trade purchasing, the questionnaire asked one question, "Do you find it difficult to purchase fair trade products?" If the respondent answered yes then the respondent was asked to explain some of the challenges encountered when trying to purchase fair trade. An open-ended question was used to diminish researcher imposed limitations in respondents' responses.

\section{Sampling Procedure}

The study used a convenience sample of Baby Boomer academic staff from a large Midwestern university in the United States. The participants in the study were recruited using two methods. First, the researcher invited people to participate in the study as they were leaving a fair trade marketplace held every fall on the campus of the university, where the researchers gave out fliers with details about the study and URL to the online survey. To increase response rates, the researchers also collected email addresses from these individuals in order to send reminders about completing the survey. The second method for recruiting participants was an email blast sent out to the academic staff at the same Midwestern university. Prior to data collection the researchers could not determine the age of the academic staff. Therefore the survey 
went out to every academic personnel within the university-not just Baby Boomers-but for the purpose of this study, only the responses from the Baby Boomers were analysed. The email included the URL for the survey. The survey was open for a period of one month. Participation reminders were sent to all non-respondents once a week.

\section{Data Analysis}

Analysis of the data from the completed surveys included a combination of both quantitative and qualitative techniques. Quantitative analysis included calculating descriptive statistics and independent-samples t-tests. The responses to the open-ended barriers question on the survey were qualitatively analysed using diffusion theory as the guiding framework.

\section{Results}

Altogether, 168 Baby Boomers, 60 male, 107 female, and one unknown, participated in the study. Out of the 168 Baby Boomers, 63 were Late Boomers, 105 were Early Baby Boomers, and all had at least a high school diploma, with a majority also having earned post-secondary degrees. Table 2 provides a complete demographic summary of the sample.

$* *$ Insert Table $2 * *$

\section{Scale Reliability and Summed Variables}

Cronbach's standardized alpha evaluated the internal reliability of each of the attitude and behaviour scales included in the survey instrument. The coefficient estimates for measures of fair trade attitudes and purchasing behaviours were acceptable at .70 or higher (Krathwohl, 1998). Therefore, based on achieving acceptable reliability estimates, summed mean score variables were calculated for respondents' attitudes about fair trade and their purchasing behaviours. Baby Boomers' Attitudes about the Fair Trade Movement 
Regarding attitudes towards fair trade, as summarized in Table 3, respondents displayed high levels of support for fair trade ideals. For example, $94.8 \%$ of the respondents agreed they were concerned with labour issues affecting people in developing countries around the world. In addition, $86.3 \%$ of the respondents believed in the goals of fair trade, while $76.8 \%$ expressed a willingness to pay more for fair trade products. On the other hand, when asked if they would settle for a lower quality garment in order to buy something from a fair trade business many of the respondents $(66.1 \%)$ either somewhat disagreed, disagreed, or strongly disagreed. This finding is compatible with previous research, which states consumers of fair trade products are not willing to compromise certain product attributes in order to purchase fair trade (De Pelsmacker et al., 2005).

** Insert Table $3 * *$

Comparison of attitudes between Early and Late Boomers. To examine possible differences in attitudes between Early and Late Boomers, using summed mean scores, an independent samples $t$-test, outlined in Table 4, was conducted to compare the attitude scores of Early and Late Baby Boomers. There were no significant differences in scores for attitudes between the Early Boomers $(M=4.53, S D=.825)$ and Late Boomers $[M=4.43, S D=.953 ; t(166)=-$ $.766, p=.45]$. Therefore, a finding of this study is that the Early and Late Boomers participating in this study were not statistically different in terms of their attitudes about the fair trade movement.

** Insert Table 4 **

Baby Boomers' Fair Trade Purchasing Behaviours 
As detailed in Table 5, respondents' answers to the FTPB scale revealed that a majority $(68.5 \%)$ of them engaged in fair trade purchasing behaviours either some of the time $(52.4 \%)$, most of the time $(13.1 \%)$, or all of the time (3\%). Additionally, almost three-quarters of the respondents agreed that they bought products from companies that they knew were concerned about human rights some of the time $(50.6 \%)$, most of the time $(16.9 \%)$, or all of the time $(6 \%)$. However, the results indicate that the number of respondents engaging in fair trade purchasing behaviours most or all of the time was low.

** Insert Table $5 * *$

In addition, Table 6 presents how frequently the respondents purchased certain fair trade products within the previous six months. The products included coffee, jewellery, clothing, chocolate, handbags, and home fashions. The most purchased fair trade item by the respondents was clothing, with $60.8 \%$ of the respondents stating that they had purchased fair trade apparel at least once in the last six months. In addition, the second highest item purchased at least once in the last six months was coffee $(60.7 \%)$ and the third most commonly purchased item was jewellery (55.3\%). The least purchased product was handbags, with only $20.5 \%$ of the respondents stating they had purchased this category of fair trade merchandise within the last six months. Furthermore, although clothing was the product the most number of respondents had purchased within the last six months, coffee had the most respondents (25\%) stating they had purchased this item seven or more times within the last six months.

$* *$ Insert Table $6 * *$

Comparison of purchasing behaviours between Early and Late Baby Boomers'. To examine possible differences in general fair trade purchasing behaviours between Early and Late 
Boomers, using summed mean scores, an independent samples $t$-test, previously outlined in Table 4, was conducted to compare the FTPB scale scores of Early and Late Baby Boomers. The $t$-test revealed no statistically significant differences in terms of the degree to which the Early Boomers $(M=2.71, S D=.849)$ and Late Boomers $[M=2.60, S D=.953 ; t(166)=-.813, p=.42]$ of this study engaged in fair trade purchasing behaviours. Therefore, similar to the Baby Boomers' attitudes, a finding of this study is that the Early and Late Boomers were not statistically different in terms of their fair trade purchasing behaviours.

\section{Barriers to Fair Trade Purchasing}

The findings from the study demonstrate that Baby Boomers, although supportive of the principles of fair trade, are not consistently engaging in fair trade purchasing behaviours. This suggests consumers may face many barriers in the fair trade consumption process. In fact, when asked, "Do you find it difficult to purchase fair trade products?" the majority of respondents $(58.9 \%)$ in this study agreed that it was challenging.

In analysing responses to why the Baby Boomers found it difficult to purchase fair trade merchandise, within the context of diffusion theory, it became evident that fair trade products often lack the prerequisites of compatibility, trialability, and observability. The data also indicate that Baby Boomers sense a level of complexity to fair trade consumption and that demonstration of the relative advantage of fair trade products over other products needs improvement.

From the responses of the respondents (for illustrative statements see Table 7), it is evident that the Baby Boomers in the study found incompatibility of fair trade products with their lifestyles to be a barrier to consumption. For example, some respondents stated they did not shop regularly and when they did, they did not usually buy the types of products typically available as fair trade. In addition, for some of the respondents, fair trade products were 
incompatible with personal finances. Compared to similar products available through mainstream retailers, fair trade merchandise usually carries a higher price point; and some of the respondents were unable or unwilling to pay this price premium. In addition, the respondents valued convenience and being able to meet multiple shopping needs in one location-which is typically not possible when acquiring fair trade products because of limited selections of fair trade items available in large retailers. Finally, related to compatibility, some respondents expressed their desire to purchase locally produced items - a criterion that the majority of fair trade items fails to meet since most fair trade merchandise is produced in developing countries.

** Insert Table 7**

Trialability of products is the second barrier to fair trade consumption identified in this study. Although some fair trade merchandise was available in the city where the university is located, assortment was minimal. Therefore, in this particular location, a consumer wanting to buy fair trade consistently and covering a variety of product categories would need to shop through catalogues or the Internet. However, purchasing mail order products limits the trialability of the product prior to purchase and some of the respondents in the study perceived this limitation as a risk.

In addition to compatibility and trialability, the data indicate that complexity of the principles grounding the fair trade movement served as a consumption barrier for the Baby Boomers in this study. The respondents argued that they found comprehending the issues surrounding fair trade and identifying fair trade companies difficult. Furthermore, respondents mentioned frustration with their perception of the constantly changing nature of fair trade policies and difficulty understanding the principles or issues grounding the fair trade movement. Compounding the barrier of the complex nature of fair trade is the fact that most of the Baby 
Boomers in the study admitted to being unwilling to spend time researching the fair trade movement as a whole, as well as the specifics of companies proposing to sell fair trade merchandise.

Finally, in discussing their perceptions regarding barriers to fair trade, the respondents discussed the observability of fair trade. According to the respondents, they were unable to find fair trade items because the products were not sold in local retail stores or because they were not labelled as fair trade on a consistent basis. Respondents mentioned one of the most helpful features of fair trade food (like coffee and chocolate) is that the fair trade certified logo is usually prominently displayed on the item and that similar labelling on other fair trade merchandise would aid in their identification and increased purchases.

\section{Discussion}

To summarize, the Baby Boomers in this study exhibited positive attitudes towards fair trade but were not willing to compromise on certain product characteristics such as quality just to purchase fair trade. Additionally, the Baby Boomers were somewhat engaged in a number of fair trade purchasing behaviours. However, only a small proportion of the Boomers in this study purchased fair trade merchandise on a consistent and frequent basis.

The Baby Boomers from this study also identified a number of barriers preventing them from purchasing more fair trade. These barriers included incompatibility of fair trade merchandise with the Boomers' lifestyles, the inability to physically touch and see, as well as try, fair trade products prior to purchase, and the lack of fair trade products in local retail stores. The Boomers also indicated it was difficult to identify fair trade products because of the absence of consistent labelling of fair trade. Finally, the respondents also discussed the complexity of issues surrounding fair trade as preventing them from purchasing more fair trade. 
Although previous research indicates there are reasons to think Early and Late Baby Boomers differ in their attitudes and behaviours (Green, 2003; Wellner, 2000; Wolfe and Snyder, 2003), this study found no significant differences between the attitudes and behaviours of Early and Late Baby Boomers regarding fair trade. However, the demographics of the Baby Boomers within this study were very similar and this may have been the reason the study found minimal differences. Therefore, before fair trade entities assume that Baby Boomers, for the purpose of fair trade consumption, are a homogeneous cohort, further research with a more generalizable sample of Baby Boomers is necessary.

\section{Marketing the Relative Advantage of Fair Trade}

Within diffusion theory the fifth prerequisite to the adoption of an innovation is relative advantage (Rogers, 1983). As previously stated, a proposition of this study is that, considering the principles of fair trade, for socially responsible consumers, the relative advantage of fair trade products over comparable mainstream products is strong. However, what is clear from this research is that fair trade entities need to be more effective in marketing the advantages of the fair trade movement and products.

As they age, Baby Boomers are becoming more socially conscious, desiring to make their existence more significant and the world a better place (Ferguson and Brohaugh, 2010; Green 2003). Therefore, in marketing their merchandise, fair trade entities should emphasize to Baby Boomers how buying fair trade directly improves the quality of life for producers and their communities (Varul, 2008). For example, through listservs, blogs, and other social networking media, fair trade entities could share stories from the fair trade producers in the developing countries, showcase the producers' daily lives, and demonstrate the benefits of being a part of the fair trade movement. Through this type of marketing Baby Boomers would become more aware 
of the relative advantage of fair trade in terms of improving the world and making a difference in others' lives.

In addition, consumers are more likely to practice socially responsible behaviours when it shows a direct benefit to them (Jøergens, 2006). Therefore, if fair trade entities hope to reach more Baby Boomers they will have to expand their marketing plans to promote the benefits not only for the producers of the merchandise but the relative advantage of fair trade for the Baby Boomers as well. Sales of fair trade products to Baby Boomers may increase if fair trade entities provided more information about fair trade product attributes and how fair trade merchandise meets Baby Boomers' consumer needs. For example, fair trade products are handcrafted, artisan made, and often one of a kind. Therefore, fair trade entities can market their merchandise as luxury products. This should be an effective marketing strategy for Baby Boomers since research indicates that $38 \%$ of Baby Boomers want to live a lifestyle of luxury (Gardyn, 2002).

Fair trade marketers should also communicate the relative advantage fair trade has in contributing towards Baby Boomers' personal development. To illustrate, fair trade entities could offer Baby Boomers volunteer opportunities to travel to and work in the communities producing the fair trade merchandise. If they had appropriate skills, the Boomers could assist with the development of product or marketing and other business strategies. This would provide the Boomers with a sense of personal development and purpose but it also may serve to increase the consumption of fair trade products because Baby Boomers would be more committed to the movement and would share their experiences with other potential consumers.

Marketing Implications of the Barriers facing Baby Boomers in the Consumption of Fair Trade

As discussed by the Baby Boomers in this study, the barriers preventing them from purchasing fair trade on a more consistent basis included the lack of compatibility with personal 
lifestyles, the lack of trialability of fair trade merchandise, the complexity of purchasing fair trade products, and limited observability of fair trade products. It is important for fair trade entities to understand these barriers and work proactively at their minimization.

Although consumers may have positive attitudes towards fair products, this study demonstrated that some consumers are not willing to sacrifice personal preferences-be it the item they purchase, the places they shop, how much they are willing to spend, or a commitment to local consumption. Therefore, to combat the barrier of lack of compatibility with personal lifestyles, fair trade entities could collaborate with larger corporate retailers to sell more fair trade products and make it more convenient for Baby Boomers to purchase fair trade. Also, fair trade entities have to consider producing more mainstream items if they want to attract new fair trade consumers. Currently, most fair trade items are ethnically styled; and there are few fair trade companies that cater to more mainstream fashion trends. Halepete et al. (2009) found that some fair trade consumers were not happy with choices of apparel because the designs, patterns, and colours were not compatible with their personal style. A large majority of the respondents in the study agreed they would be more willing to purchase fair trade products if there was a greater range in product selection. Therefore, Baby Boomers may increase their consumption of fair trade if the selection expanded to meet a greater range of consumer needs and personal tastes.

Additionally a large deterrent for purchasing fair trade is the higher prices of the products. Although basic economic principles state that as the consumption of fair trade products increases, prices will decrease; from a marketing perspective a more practical solution may be to market the benefits of purchasing fair trade and helping consumers have a better understanding of why it may cost more. Also for those that do have more disposable income, showcasing how 
fair trades meet their needs and benefit others (the relative advantage) may help them be able to justify purchasing fair trade, even if it does cost more.

Fair trade companies also need to find creative ways to promote trialability of fair trade products to create stronger sales within the Baby Boomer market. To aid in making Baby Boomers more comfortable with purchasing fair trade products online or through a catalogue, fair trade entities should consider their return policies. Consumers may be more willing to purchase an item online if it is easy and affordable to return. Many mainstream e-retailers include return packaging and shipping labels with the product and some even prepay the return shipping costs. Fair trade entities should consider adopting similar practices. Fair trade retailers could also improve trialability by including a free fair trade item with the purchase of another item. This could also be good way to test market new fair trade products.

Online fair trade retailers could also redesign their websites to reduce the perceptions of risk associated with online shopping and entice the consumer to purchase. Research has shown that although consumers perceive some risks when purchasing online there are ways to combat these perceptions. When purchasing apparel, sensory attributes such as fabric, fit, colour, and quality are important decision-making criteria. A way to offset negative consumer perceptions related to online shopping is to create an attractive and easy to navigate visual of the product. For example, three important features of an appealing online visual presentation are presenting products in use, displaying products with similar items, and displaying products from multiple angles (Park et al. 2005). Therefore, fair trade entities should implement these features on their own websites, as well as highlight products' attributes and create appealing online visuals for apprehensive Baby Boomers. 
In order to combat the barrier of the complexity of purchasing fair trade products, fair trade companies may benefit from teaming up with a popular brand that is showing environmental and ethical initiatives in their business practices. This partnership could be twofold - with more consumers learning about fair trade and what it means to shop ethically and, at the same time, reforming consumer thoughts on the popular brand. Starbucks Coffee is an example of a company that, in the 1990s, had public image problems related to corporate social responsibility. The company eventually formed a partnership with TransFair USA and is now the leading fair trade coffee purchaser, selling fair trade certified coffee in their stores and online (“PR Industry's Analysis of OCA's Starbucks Campaign,” 2001). Selling fair trade coffee at Starbucks significantly reduces the complexity of purchasing fair trade for consumers because it is a business that many consumers already commonly visit and trust.

"Consumers may find it difficult to consider several ethical aspects simultaneously" and consumers tend to want to focus on one cause at a time (Uusitalo and Oksanen, 2006: 215). Therefore, fair trade companies may also reduce the complexity and increase sales by strategically concentrating on one issue — and effectively communicating the message of that issue to consumers. For example, Uusitalo and Oksanen (2004) found that many consumers readily understand that The Body Shop produces ethically produced personal care items that are not tested on animals. Similarly, within the fair trade movement, Awava is a fair trade company that focuses on helping women in Uganda by providing economic empowerment. Awava's message is clear, which could make it easier for Baby Boomers to know from where the product is produced and who benefits from their purchases (Awava, 2012). Other fair trade entities could benefit from simplifying their message and having better branding for their cause. 
The limited observability of fair trade was the last barrier identified in this study. Observability may be one of the most complex factors for fair trade products, especially apparel — the majority of which is not labelled as fair trade. Without this labelling, consumers make inferences about whether the product is or is not ethically produced. A solution to help fair trade to be more visible would be a "label containing ethical information in a condensed format issued by a truthful source" (Jøergens, 2006: 368). One suggestion for improving the labelling of fair trade products would be to label fair trade merchandise with quick response (QR) codes that consumers could scan with their phones and receive up-to-date and detailed product information from trustworthy third-party websites.

Ultimately, fair trade organizations would benefit from some consistency in fair trade labelling especially on non-perishable items. Fair trade entities need to make sure their purpose is clearly stated and displayed and need to look into expanding into other markets. Respondents in this study exhibited a need for more retailers for fair trade products. Fair trade entities may want to take this information and consider opening new stores in geographical locations with high concentrations of Baby Boomers.

\section{Conclusion}

The purpose of this research was to expand the body knowledge related to fair trade consumption by examining Baby Boomers' fair trade attitudes and purchasing behaviours. While research suggests ethical consumption is on the rise and more mature consumers are buying fair trade products, there are still many barriers inhibiting fair trade consumption. As proposed by the ABC model, "actions or behaviours (B) are associated with attitudes (A)... Actions also have external conditions (C) associated with them" (Guagnano et al., 1995: 702). According to the ABC Model, if the external conditions working against fair trade consumption are minimal, 
consumers with favourable attitudes towards fair trade are more likely to engage in fair trade purchasing behaviours that are consistent with those attitudes. However, if the external conditions are such that it becomes difficult to engage in fair trade consumption, attitudes and behaviours are likely to be inconsistent.

According to this study, internal factors of Baby Boomers' (their attitudes) are conducive for purchasing fair trade. However, the study found the compatibility and complexity of fair trade products to be external barriers to fair trade consumption. Additionally the study found other external conditions (such as price, quality, trialability, observability, convenience) hindering Baby Boomers from consistently engaging in fair trade purchasing behaviours. Therefore, the conclusion of this study is that at least some Baby Boomers have positive attitudes towards fair trade. However, external barriers do exist, and only in minimizing these barriers will the positive attitudes influence and increase fair trade purchasing behaviours. Therefore, a logical way to expand the current study would be to look to find effective ways for overcoming the barriers.

Although this study resulted in a number of important findings, there are also limitations and areas for future research. An obvious limitation was the sample was well-educated university academic staff from one U.S. higher education institution and it is not representative of all Baby Boomers. Therefore, a suggestion for increasing the generalizability of the study would be to obtain a sample more representative of U.S. Baby Boomers. In addition, data collection could expand to Baby Boomers in other countries for a cross-cultural analysis and increased relevance on an international scale. Furthermore, related to diffusion theory, this study only focused on the necessary prerequisites for the adoption of an innovation and did not examine other elements of the theory related to the diffusion and adoption process-leaving other avenues open for 
exploration. For example, Fliegel and Kivlin (1966) expanded the original iteration of diffusion theory by developing additional characteristics of an innovation including financial cost, social cost, return to the investment, risk associated with the product, and efficiency of the product. Further research could be done to explore the role these characteristics play in fair trade consumption. 


\section{References}

Adams, M. and Raisborough, J. (2008), "What can sociology say about fair trade? Class, reflexivity and ethical consumption", Sociology, Vol. 42 No. 6, pp. 1165-1182.

Awava. (2011), About Awava. Available at http://awavamarket.com/about-awava (accessed 22 March 2011).

Barnett, C., Cloake, P., Clarke, N., and Malpass, A. (2005), "Consuming ethics: Articulating the subjects and spaces of ethical consumption”, Antipode, Vol. 37 No. 1, pp. 23-45.

Bird, K. and Hughes, D. (1997), "Ethical consumerism: The case of "fairly-traded" coffee", Business Ethics: A European Review, Vol. 6 No. 3, pp. 159-167.

Castaldo, S., Perrini, F., Misani, N., and Tencati, A. (2008), "The missing link between corporate social responsibility and consumer trust: The case of fair trade products", The Journal of Business Ethics, Vol. 84, pp. 1-15.

Connolly, J., and Shaw, D. (2006), "Identifying fair trade in consumption choice", Journal of Strategic Marketing, Vol. 14, pp. 353-368.

De Pelsmacker, P., Driesen, L., and Rayp, P. (2005), "Do consumers care about ethics? Willingness to pay for fair trade coffee", The Journal of Consumer Affairs, Vol. 39 No. 2, pp. 363-385.

Dickson, M.A. (1999), "U.S. consumers' knowledge of and concern with apparel sweatshops", Journal of Fashion Marketing and Management, Vol. 3 No. 1, pp. 44-55.

Dickson, M.A. and Littrell, M. (1996), "Socially responsible behaviour: Values and attitudes of the alternative trading organization consumer", Journal of Fashion Marketing and Management, Vol. 1 No. 1, pp. 50-69.

Dickson, M. A. and Littrell, M. (1997), "Consumers of ethnic apparel from alternative trading organizations: A multifaceted market", Clothing and Textiles Research Journal, Vol. 16 No. 1, pp. 1-10.

Downie, A. (2007), "Fair trade in bloom", The New York Times. Available at http://www.nytimes.com/2007/10/02/business/worldbusiness/02trade.html?pagewanted=all (accessed 24 January 2013).

Fairtrade International. (2012), "For producers, with producers: Annual report 2011-2012", available at http://www.fairtrade.net/fileadmin/user_upload/content/2009/resources/2011 12_AnnualReport_web_version_small_FairtradeInternational.pdf (accessed 24 January 2013).

Fair Trade USA. (2011), "2011 almanac", available at http://fairtradeusa.org/sites/default/files/Almanac\%202011.pdf (accessed 22 January 2013). 
Ferguson, R. and Brohaugh, B. (2010), “The aging of Aquarius”, Journal of Consumer Marketing, Vol. 27 No. 1, pp. 76-81.

Fliegel, F.C. and Kivlin, J.E. (1966), “Attributes of innovations as factors in diffusion”, American Journal of Sociology, Vol. 72 No.3, pp. 235-248.

Forney, J., Park, E.J., and Brandon, L. (2005), "Effects of evaluative criteria on fashion brand extension”, Journal of Fashion Marketing and Management, Vol. 9 No. 2, pp. 156-165.

Gardyn, R. (2002), "Defining luxury: Oh, the good life”, American Demographics, Vol. 24, pp. 30-35.

Green, B. (2003), Marketing to Leading-Edge Boomers, Brent Green and Associates Inc., New York, NY.

Guagnano, G.A., Stern, P.C., and Dietz, T. (1995), "Influences on attitude behaviour relationships: A natural experiment with curbside recycling", Environment and Behaviour, Vol. 27 No. 5, pp. 699-718.

Hainmueller, J. and Hiscox, M.J. (2012). "The socially conscious consumer? Field experimental tests of consumer support for fair labor standards", working paper [2012-15], Department of Political Science, Massachusetts Institute of Technology.

Halepete, J., Littrell, M., and Park, J. (2009), "Personalization of fair trade apparel: Consumer attitudes and intentions", Clothing and Textiles Research Journal, Vol. 27 No. 2, pp. 143-160.

Hiller Connell, K.Y., and Kozar, J.M. (2012a), "Social normative influence: An exploratory study investigating its effectiveness in increasing engagement in sustainable apparel-purchasing behaviors", Journal of Global Fashion Marketing, Vol. 3 No. 4, pp. 172-179.

Hiller Connell, K.Y. and Kozar, J.M. (2012b), "Sustainability knowledge and behaviours of apparel and textile undergraduates", International Journal of Sustainability in Higher Education. Vol. 13 No. 4, pp. 394-407.

Hulm. P. (2006), "Fair trade: What does fair trade mean? You won't find one single answer", International Trade Forum, April-June, pp. 15-20.

Hurley, T. (2010), "Baby boomer statistics", available at http://seniors.lovetoknow.com/Baby_Boomer_Statistics (accessed 30 October 2010).

Jøergens, C. (2006), “Ethical Fashion: Myth or future trend?", Journal of Fashion Marketing and Management, Vol. 10 No. 3, pp. 360- 371.

Krathwohl, D.R. (1998), Methods of Educational and Social Science Research, (2nd ed.), Addison-Wesley Educational Publishers, New York, NY. 
Kozar, J.M. and Hiller Connell, K.Y. (in press), "Socially and environmentally responsible apparel consumption: Knowledge, attitudes, and behaviours", Social Responsibility Journal.

Kozar, J.M. and Hiller Connell, K.Y. (2010), "Socially responsible knowledge and behaviours: Comparing upper- vs. lower-classmen”, College Student Journal, Vol. 44 No. 2, pp. 279-293.

Littrell, M., Ma, Y., and Halepete, J. (2005), "Generation X, Baby Boomers, and Swing: Marketing fair trade appare",. Journal of Fashion Marketing and Management, Vol 9. No. 1, pp. 407-420.

Moore, G. (2004), “The fair trade movement: Parameters, issues and future research", Journal of Business Ethics, Vol. 53 No. 1-2, pp. 73-86.

Morrissey, M. (2012), "New fed data shows families falling even farther behind in retirement saving", available at http://www.epi.org/blog/fed-data-shows-families-falling-retirement/ (accessed 22 January 2013).

Neal, S. (2010), "Small businesses cater to gray", available at http://www.allbusiness.com/print/6797357-1-22eeq.html (accessed 21 September 2010).

Nicholls, A. (2002), "Strategic options in fair trade retailing", International Journal of Retail and Distribution Management, Vol. 30 No. 1, pp. 6-17.

Niinimaki, K. (2010), "Eco-clothing, consumer identity and ideology", Sustainable Development, Vol. 18 No. 3, pp. 150-162.

Nyren, C. (2005), Advertising to Baby Boomers, James Madden, Ithaca, NY.

Ozcaglar-Toulouse, N., Shiu, E., and Shaw, D. (2006), "In search of fair trade: Ethical consumer decision making in France", International Journal of Consumer Studies, Vol. 30 No. 5, pp.502514.

Park, J., Lennon, S., and Stoel, L. (2005), “On-line product presentation: Effects on mood, perceived risk, and purchase intention", Psychology \& Marketing, Vol.22. No. 9, pp. 695-719.

"PR industry's analysis of OCA's Starbucks campaign: Cyber-attack against Starbucks shows what to do when a crisis brews", (2001). available at http://www.organicconsumers.org/starbucks/pr.cfm (accessed 17 August 2012).

Rogers, E.M. (2003), Diffusion of Innovations, $2^{\text {nd }}$ edition, The Free Press of Glencoe, New York.

Scarborough Research. (2012), "Keeping up with the Baby Boomers: Scarborough study reveals insights into Baby Boomers' entertainment spending”, available at http:// 
http://www.scarborough.com/press-release.php?press_id=keeping-up-with-the-baby-boomers (accessed 22 January 2013).

Shaw, D., Hogg, G., Wilson, E., Shui, E. and Hassan, L. (2006), "Fashion victim: The impact of fair trade concerns on clothing choice", Journal of Strategic Marketing, Vol. 14, pp.427-440.

Stern, P.C. and Oskamp, S. (1987), "Managing scarce environmental resources", in Stokols, D. and Altman, I. (Eds.), Handbook of Environmental Psychology, Wiley, New York, pp. 10441088.

U.S. Census Bureau. (2011), "Profile of general population and housing characteristics: 2010 demographic profile data", available at http://factfinder2.census.gov/faces/tableservices/jsf/pages/productview.xhtml?pid=DEC_10_DP_ DPDP1\&prodType=table $($ accessed 5 December 2011).

U.S. Department of Labor. (2012), "Consumer expenditure survey", available at http://www.bls.gov/cex/ (accessed 22 January 2013).

Uusitalo, O. and Oksanen, R. (2004), "Ethical consumerism: A view from Finland", International Journal of Consumer Studies, Vol. 28 No. 3, pp. 214-221.

Varul, M. (2008), "Ethical selving in a cultural context: Fair trade consumption as an everyday ethical practice in the UK and Germany", Fair Trade International Symposium, Montpelier, France, 14-16 May 2008.

Verdier-Stott, J. (2009), "Labels, lies and the law: Opportunities and challenges in mainstreaming fair trade", Social Justice \& Global Development Journal (LGD) [online] available at http://www.go.warwick.ac.uk/elj/lgd/2009_1/verdier-stott (accessed 24 March 2011)

Wellner, A.S. (2000), “Generational divide”, American Demographics, Vol. 22, pp. 52-58.

Wolfe, D. and Snyder, R. (2003), Ageless Marketing: Strategies for Reaching the Hearts and Minds of the New Customer Majority, Dearborn Trade Publishing, Chicago, IL. 